Copyright (C) 2017 by Academic Publishing House Researcher

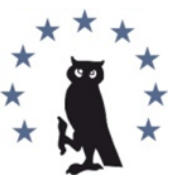

Published in the Russian Federation

European Researcher. Series A

Has been issued since 2010.

ISSN 2219-8229

E-ISSN 2224-0136

2017, 8(3): 176-182

DOI: $10.13187 /$ er.2017.3.176

www.erjournal.ru

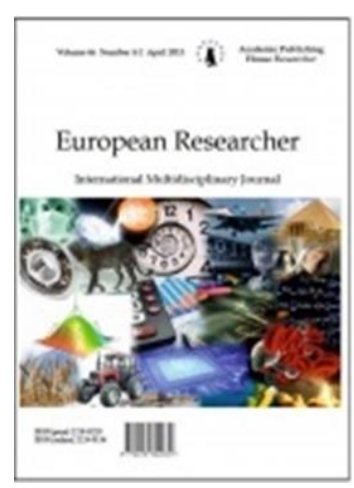

UDC 33

\title{
A Study on Human Trafficking with Special Focus on Tribal Women of Jharkhand
}

\author{
Sribas Goswami a * \\ ${ }^{a}$ Serampore College, Hooghly, West Bengal, India
}

\begin{abstract}
The sale for women and girls accounts for the greatest proportion of human trafficking in India and globally too, trafficking of women and girls is an offence against humanity and is an organized crime. In India the State Jharkhand is acting as the illegal industry's largest national hub. An estimated 33,000 girls are trafficked each year from Jharkhand. Most of such victims of trafficking and exploitation are below 18 and illiterate or semi-literate and are forced to work in household, brothels, restraints and factories. Human trafficking is one of the most heinous forms of organized crime and violation of human rights in the world and makes a mockery of basic human rights of the vulnerable. It victimizes men, women, and girls for various purposes such as labor in factories, farms, and private households, sexual exploitation, and forced marriage. Traffickers take into account neither law nor national system and their only objective is profit, by trafficking in human beings. Whether through abduction or fraud, they deceive desperate people whose dream of being freed from poverty is transformed into the worst of nightmares. Trafficking affects all regions and most countries of the world, Inequalities and growing demand for cheap, disempowered labor are just some of the underlying causes that have been identified. The exploitation of individuals for profit has a long history and dates from well before the birth of the modern human rights system. Since the issue of human trafficking in Jharkhand is a wide phenomenon, the research is exclusively focusing on cause of trafficking of the adivasi (tribes) women and girls of Sahibganj district, Jharkhand, India. This research is concentrated on two blocks of Sahibganj district of Jharkhand.
\end{abstract}

Keywords: human trafficking, poverty, patriarchy, migration, tribe.

\section{Introduction}

\section{BCSPG9062K 9635789880}

Jharkhand has emerged as India's trafficking hub with thousand of tribal women and girls being trafficked out of state each year to Delhi, Punjab and Haryana and beyond. An estimated 33,000 girls are trafficked each year from Jharkhand. Most of such victims of trafficking and exploitation are below 18 and illiterate or semi-literate and are forced to work in household, brothels, restraints and factories. The causes of trafficking are mainly poverty, lack of livelihood opportunities, backwardness and low awareness among the tribal communities; desire to lead a better life in big cities, etc. While most of these girls go out for work, there has been a rise in the

\footnotetext{
${ }^{*}$ Corresponding author

E-mail addresses: sribasgoswami@gmail.com (S. Goswami)
} 
case of sex trafficking in the state too. Several districts of Jharkhand are affected with human trafficking and Sahibganj is one of those trafficking affected district.

There is a growing evidence of increasing human trafficking as a modern form of slavery (Abraham, 1987). And the worst form of human trafficking is related to women and girls being trafficked for cheap and forced labor, sexual exploitation. It is supplemented (UNODC) and defines, trafficking in persons as the recruitment, transportation, transfer, harboring, or receipt of person's, by means of the threat or use of force or other forms of coercion, of abduction, of fraud, of deception, of the abuse of power or of a position of vulnerability or of the giving or receiving of payments or benefits to achieve the consent of a person having control over another person, for the purpose of exploitation.

The concept of human trafficking refers to the criminal practice of exploiting human beings by treating them like commodities for profit. Girls and women are bought and sold with impunity and trafficked and are forced to work as sex workers, undergoing severe exploitations and abuse. Due to unrelenting poverty and lack of employment opportunities there is an increase in the entry of women into sex and non-sex works.

\section{Method of research}

This paper is an outcome of empirical research which is explanatory in nature. The research involves both qualitative and quantitative methods. It tries to analyze the problems and at the same time find out the factors leading to the trafficking of women and the girls. Empirical study is based on questionnaires with the government officers, victims of trafficking, and village heads, local community. Various books from different libraries, articles, journals, newspaper cutting have been used as secondary sources for data collection.

Sahibganj district is one of the twenty-four districts of Jharkhand state. Set within the lush green region, the district of Sahibganj with a predominantly tribal population, is one of the six districts comprising Santhal Pargana division. It is considered as one of the backward district of India. Sahibganj have a history of being among the least - developed in the whole country.

The vast tract of land enclosed between the hills ranges had been assigned these names; Damin-I-Koh is a Persian word and means 'skirt of the hills". The district may be divided into three natural divisions. One is the hilly portion, consists of the uplands, undulations long ridges and depressions which is inhabited by the tribal. Second portion, this area has plenty of fertile lands and is richly cultivates and majority inhabited by non-tribals (Banerji, 1986). The third region is a narrow strip of low, fertile, alluvial plain lying between the Ganges and the hills running along the loop line of the Eastern Railway inhabited by majority non-tribal constituencies, Census 2011 figures indicated that the percentage share of scheduled caste population to total population was $6.29 \%$ while that of Scheduled tribes was $26.80 \%$. The total number of villages in the district is 1,819. Of these, 1,307 are inhabited and 512 uninhabited. Males constitute $51.33 \%$ of the population and females $48.66 \%$. Among the tribes the Santhals are in the majority.

\section{Discussion}

\section{Various issues of human trafficking}

\section{BPL (Below poverty line) and electricity connection}

The disadvantaged social groups in remote rural areas of the district are the worst victims of poverty. Rural population is afflicted by malnutrition and ill-health, because poverty and under nutrition and ill-health are intricately inter-related to each other. Private money lending is still expanding its tentacles in the rural areas and constitutes a thriving tool of exploitation. Based on the number of the total rural households (Bhagat, 2001). In Census 2011 BPL Revision Survey, the percentage of BPL households in rural areas is $86.03 \%$ in the district. Sahibganj district has 54,730 BPL households excluding Annapurna Antodaya Yojana families as on 2013 survey report. The distribution among economic classes provides further strength to that argument on account of the fact that 71.5 per cent of all migrant child workers and 67.2 percent of trafficked children are from below poverty line and AAY (Annapurna Antodaya Yojana) households.

The condition of rural electrification is not good. The proportion of households with electricity connection is very low in Sahibganj district. In more than 95 percent of the villages with high tribal density and forests, such as Borio, Barhait, Mandro and Udhawa, electricity supply is poor. Only 18.8 percent of the households were electrified. Around $99 \%$ of the households across 
all communities depends oil lamps for lightening purposes. Even if there is connection, only a few people get electricity continuously for 10 hours in a day.

\section{Minerals and Industry}

Sahibganj is predominantly a hilly district. The Rajmahal Hills are the source of building and road stones. Kaolin is found near Mangal hill in Rajmahal subdivisions. Bentonite, available in some places, is used by women-folk as hair washing material as Multani Mitti (Fuller's Clay or Fuller's Earth kind of clay material that has the capability to decolorize oil or other liquids without chemical treatment). Black stone, coal and China clay are available in Sahibganj district. Rajmahal has coal deposits in about 520 square $\mathrm{km}$, which has the estimated coal reserves of 2,680 million tons.

Sahibganj district contains a large number of stone mines and crushers. Approximately 100 mines and 150 crushers, 200 pottery and Clay washing industries are in operation with the support of a huge labor force. Kaoline and Bentonite are of superior quality and they are also exported to South Asian countries. Stone chips, pottery, and clay washing manufacturing are there source of income generation for a significant proportion of the people of the district (Maharaj, 1982).

\section{Poverty and poverty plus factor}

Almost all studies and reports related to trafficking in Sahibganj and the whole of Jharkhand emphasize poverty as the major underlying factor for trafficking of women in general and minor girls in particular. Women and minor girls attributed their entry into trafficking because of poverty. The poverty alleviation programmers have performed poorly. The inadequate assistance did not help the beneficiaries cross the poverty line in terms of income. The situation in Sahibganj is more desperate, there is depth of poverty and lack of food security. Landless , marginal farmers, lack of sustainable employment and livelihoods, poor irrigation facilities for agriculture, single crop patterns, has caused immense poverty among the tribal population making them vulnerable to trafficking, particularly women and girls to agreeing to unsafe migration, which then ends up them as victim of trafficking (Kumari, 2001).

Poverty is one the primary risk factors to create vulnerability to trafficking however; poverty alone would not push people into human trafficking (Chrristina, 2008). There are many risk factors that make potential victims vulnerable to trafficking, and a combination of such factors, and poverty is referred to as "poverty plus", such as illness, family crisis or other stress factors, combines with poverty to increase the vulnerability of individuals to trafficking. It is reported that girls from Jharkhand being lured to Delhi with dreams of a good future, motivation to help the family and dreams of economic betterment ending up losing their life within two weeks of migration, show the total vulnerability of girls and women. Government schemes such as MNERGA (Mahatma Gandhi National Rural Employment Guarantee Act) that could provide a living wage during periods of underemployment, but are not properly implemented in the district, thereby depriving poor rural household of sustained employment (Kannongo, 2001).

\section{Landlessness and patriarchy}

The indigenous communities throughout the world share a common history of land alienation and resources exploitation and the worst victims of this alienation are women (Erni,2012). The status of tribal women in Jharkhand is lower than the tribal men. Women have lagged behind men in all respect. Owing to the fact that trial society is dominated by men, women suffer under oppression structures. According to the Chotanagpur Tenancy ACT and Santhal Parganas Tenancy Act, only an unmarried daughter has right to sustain herself from fathers land. A married Daughter, even if she is the only daughter, however loses the right. Land is passed on almost exclusively along the male lines. Customary laws is usually more strictly applied. But a widow is supposed to have a right to maintain herself from her husband's land and property. The status of tribal women has gone from bad to worse as a result of socio-economic change (Christopher, 2008).

The rural sector of Jharkhand and in Sahibganj district includes the largest concentration of scheduled tribes and scheduled castes. A large percentage of the rural households and land poor. Landlessness and resultant decline of rural livelihoods is a major push factor for migration and obviously has an important role in driving trafficking in Sahibganj. According to the socioeconomic and Caste Census 2011 published by government of India ,38 \% of households in rural areas of the country are landless and are engaged in manual casual labour. According to 2011 survey, Sahibganj has 86 per cent people lives in rural areas and landlessness is very high among 
rural households of Sahibganj district. Dependency levels are high, with approximately $60 \%$ of the population below the age of 14 years, with half of these being in the 5-14 age groups.

Landlessness and the small average holding size limit possibilities for livelihoods as wheel as slow agricultural growth, and makes it necessary for the rural poor to work as casual labor in agricultural sector at low wages (Dayal, 2001). Women work as casual laborers in agriculture. Because of the shrinking land holding by the local populace, and even if they appears as landowning people, the degradation of land to a great extent due to deforestation, mining activities and rampant industrialization they are vulnerable to poverty, and their economic conditions render them vulnerable to poverty and food insecurity. Their lands are often barren, lack irrigation and, at best, produce single crops that are not enough to provide them with food and income security. According to the 2002 Land Reform Report the land distributed among the landless was 28, 28,937 acres and 12, 87,786 acres remained undistributed in the whole state. Nearly 7.62 lakhs acres remained as balance land for distribution

Thus, landlessness are the small size of land holdings possessed by tribal households not only to reduces the livelihood options but also makes them vulnerable to low wage workers, which fetters the landless households in the poverty trap (Khanna, 1998).

Education, unemployment and work participation:

The survey in 2011 shows, literacy rates have improved to $53 \%$, though it is still below the national average of $74.4 \%$ and the gender gap has narrowed but still prevail with male literacy at $60.34 \%$, and female literacy at $39.53 \%$. Literacy rates are lower than the average among both ST and SC population, in which female literacy is even lower. The target of education for all, is still a distant dream and the quality of education being imparted in schools need to be improved on a priority basis. The availability of secondary, higher and technical education in the district is still a major deficiency and concerted efforts are required to improve these facilities. A survey of trafficked adult women attributed their entry to such factors as lack of basic facilities of education, illiteracy and ignorance. At the individual level, limited education has been emphasized as a risk factor (Dewan, 2006).

\section{Slow agricultural development:}

According to the society for Regional Research and Analysis 2010, about $91.7 \%$ of tribal population is based in rural and forest area and are mainly agriculturist-cum-gatherers. They earn their livelihoods or wages as agricultural laborers, forest and seasonal laborers.

In the majority of the regions, there is one crop pattern and mainly rain fed cultivation takes place. As per 2011 Census between only $10 \%$ to $20 \%$ irrigation potentially has been created in Sahebganj. Lack of agricultural operations in a full-fledged manner is also leaving the landless labor high and dry. The only option available to them is migration. Thus during the nonagricultural seasons one can witnessed exodus from the villagers in search of work to the very far states. In recent years they have been migrating due to lack of employment, poverty, displacement, natural calamity and from internal conflict areas. These factors also force them to lose their traditional source of livelihood (Jeyaraj, 2008).

Tribal households derive their livelihood from self-employment in agriculture and allied activities, casual wage labor in agriculture and non agriculture (Fernandes, 1987). Comparatively a larger number of females than makes are engaged in casual wage labor in agriculture and the opposite is true of casual wage-labor in non-agriculture. Overall, high dependence on casual wage labor in agriculture and non-agriculture reflects the poor economic condition of the households. This forces the women to work outside the households in precarious conditions at very low wage. The low crop yield in Sahibganj district is accounted for by the fact that the farmers rely largely on the traditional inputs and technology and make less use of modern inputs like fertilizers, high yielding variety seeds, irrigation etc. A high proportion of poor households derive their livelihood on a day today basis by working as casual laborers in agriculture and non-agriculture sectors.

The male marginal workers in the district are $7.61 \%$, according to 2011 Census. OUT of total 390,363 workers, the number of rural workers is 366,141 and 24,222 is the number of urban workers. The work participation is modest. Gender differential in work participation is noticeable in all the communities; $51.42 \%$ for males and $32.19 \%$ for females. Overall, low male work participation is reported across communities, which needs to be improved by providing work opportunities through NREGA (National Rural Employment Guarantee Act). Low female work participation calls for appropriate policy interventions to raise their employment so that they are 
empowered and play their roe within and outside the family in an effective way.IN term work participation, tribal women in rural areas, normally work for 12 to 14 hours a day, enjoy less leisure as compared to their male counterparts, who work for 7 to 9 hours. Therefore stagnant agricultural growth and more work participation by female are responsible for trafficking of tribal women and girls in the district (Mies, 1986).

\section{Victims of industrialization:}

Deforestation, mines excavation and related settlements and need based arrangements affected the land and tribal people adversely (Fuchs, 1992). People in the region became alienated from their land and society, for mining and industrialization in the names of national interest due to their illiteracy and ignorance. When people are displaced socially and culturally, its impact fell on the income of the men folk to the family contribution, which is almost insignificant. There is no large-scale industry in the area mainly due to lack of infrastructure support, especially in areas of insufficient road connectivity and electrification.

Mining and crusher industries ruin the land, water, forest and air. Mining enterprise means, the conversion of land to the purposes of roads, railways and ropeways for mineral transport, townships for housing miners and managers, infrastructure for administrative purposes, land for stocky yard and preliminary processing operations. In effect, the total land affected by mining is many times higher than the simple lease area. Waste dumps to the adjoining agricultural fields makes uncultivable. So the tribal's are greatly affected by it and since the women are the suppliers of food, so they are the one who are most affected by this. The negative effects are more felt by the tribal women than the men.

\section{Victims of migration}

Rural women contribute to economic activities and family well-being. An emerging phenomenon in the rural scene is a female headed family due to large scale migration of men seeking employment in the urban sector (George, 2014). The women have to assume the role of the head of the household and are responsible for looking after the children and the elderly, embers of the family.

Further, extreme poverty among women and their continuing marginalization in society, forces many to seek a better life, and therefore they are too are desperate to migrate to cities in search of livelihood. Young women living in poverty who want to help their families by moving to cities are often finding deceived, because they were lured into migration with promise of legitimate jobs, but landed up in domestic servants, prostitution, forced labor and sold for marriage. Migrant women generally get employed in the maid industry, sex and marriage industry. Majority of the single migrant women then become infected with HIV positive (Mehta, 1982).

\section{Push and pull factors of trafficking}

There are two major factors leading to trafficking. The first one is supply factor and the other is demand factor. In other words, this is called Push and Pull factor. Poverty, natural; disasters drought, etc, domestic violence, unemployment, lure of job, weak bondage within the family, cultural silence, illiteracy and ignorance are the supply factors; the demand factors are: migration, hope for jobs, demand for cheap labour, enhanced vulnerability due to lack of awareness, creation of need and market by traffickers. The demand side also includes sex tourism, cheap labor (Gupta, 2001).

The supply side includes also discrimination, lack of livelihood options, lack of family support, traditional views towards women, impact of globalization on livelihood through the removal of traditional agricultural jobs and small scale and cottage industries. Lack of good job opportunities and hope of better lives are the factors that make women and minor girls vulnerable to trafficking.

\section{Family and individual factors}

Disruption of family life because of domestic violence, illness odd death of income - earning family members and husband's alcoholism and extramarital behaviors, martial separations or abandonment were also significant factors in putting women and minor girls at risk of trafficking. A study of rescued girls who were trafficked as minors found reported family disruptions as predisposing factors. Factors such as death or illness of income-earning family members and martial disruptions are cited in several other studies of women and minor girls as predisposing factors (Mitra, 2013). 


\section{Lack of political will and caste factor}

Lack of political will is one of the main causes for the failure of the rural development like agriculture and education (Jayaswal, 2001). Therefore there is danger of both officials and nonofficials hobnobbing with one another against the interest of the people. There is no accountability and transparency by the officials and non-officials, and therefore not much can be expected for genuine rural development. The social and economic indicators of Sahibganj are among the worst in the country. Even though the district is rich in minerals, the inequitable distribution of wealth and lack of political will plague the district. Corrupt government officials, lack of adequate legislation and of political will and commitment to enforce existing legislation or political mandates are other factors that facilitate trafficking in persons. In response to the above root cause, most prevention strategies fall within one of the following categories: illiteracy, lack of sustainable employment, poor irrigation facilities for agriculture, single crops patterns, lack of awareness and political instability are some reasons that make people vulnerable to trafficking.

\section{False promise of job}

The process of trafficking starts with the source trafficker approaching a potential victim based on the various vulnerabilities (Iyer, 1986). Weekly market or fairs were popular locations for traffickers to approach potential victims. While there are cases of girls being lured without the knowledge of their family members, at times the family members also willingly send their children with 'agents' to find work in bigger cities. The agents might promise them some salary and job as domestic help but this never reaches the family and the job may end up being worse than what was promised.

\section{Sectors of exploitation}

Tribal women and girls account for the most of the trafficking victims and survivors of trafficking. They are mainly exploited for domestic labor, marriage and to brick kilns. Women and girl from Jharkhand are being trafficked for marriages to Haryana and Punjab. Given the low sex ration in these regions, trafficking of women and girls from poverty stricken tribal villages of Jharkhand is turning out to be profitable for traffickers. Many of the children are working in the carpet sector also. Apart from these, trafficking for illegal adoption rackets are forced surrogacy has been reported recently. This is the most common sector where trafficked victims from Jharkhand are exploited.

\section{Conclusion}

The findings shows poverty, vulnerability to food insecurity, lack of employment, decline of agriculture, failure of the state to provide irrigation, lack of crop insurance, and failure of the agencies entrusted with child protection to discharge their responsibilities to be the root cause of tribal women and girls trafficking in Jharkhand. However, in the absence of irrigation, rain-fed agriculture did not provide them with adequate food. Land related poverty, i.e. landlessness, lack of sustainable livelihoods make a large majority of rural households extremely vulnerable to poverty and lack of food security. A high proportion of women and girls trafficked because of poverty, lack of livelihood opportunity, lack of access to education and the huge disadvantages in education. As majority of the population rural and tribal of district Sahibganj, and agriculture is the main source of income and they depend on traditional method of agriculture. There is another important concern that the tribal of this district are also victims of corrupt officials and politics. The three major areas economic, education and employment, the district needs to develop, so that the poor, specially the women and girls who fall prey to trafficking can be rescued from this inhumane activity as well as they can have a life with dignity.

\section{References}

Resley, 1987 - Resley, Abraham (1987). We Experience Christ More in Our Struggle than in Biblical Phrases. To Set At Liberty Those Who Are Oppressed? Singapore: Christian Conference Asia.

Sumanta, 1986 - Sumanta, Banerji (1986). Rural Scene. In Agrarian Struggles in India, edited by A.R. Desai, Delhi: Oxford University Press.

Bhagat, 2001 - Bhagat, L.N. (2001). Backwardness and Development of Jharkhand: Some Basic Issues. In Backwardness of Jharkhand: Causes and Remedial Measures edited by L.N. Bhagat and U.K. Verma, Chakradharpur: Jawahar Lal Nehru College. 
Deborah, 2008 - Chrristina, Deborah (2008). Struggle Against Land Alienation - A Study of Mahasweta Devi's Short Story 'Little Ones. In Human Rights and Higher Education, edited by Lily Balasingh, Briget Mary,and Jesudasan Jeyaraj. Madurai: Lady Doak College Publication.

Kalaneethy, 2008 - Kalaneethy, Christopher (2008). Christian Perspective of Children's Right. In Human Rights and Higher Education, edited by Lily Balasingh, Briget Mary, and Jesudasan Jeyaraj, Madurai: Lady Doak College Publication.

Harishwar, 2001 - Harishwar, Dayal (2001). Jharkhand: An Abode of the Poor and Deprived. In Backwardness of Jharkhand:Causes and Remedial Measures edited by L.N.Bhagat and U.K.Verma, $1^{\text {st }}$ ed. Chakradharpur:Jawahar Lal Nehru College.

Dewan, 2006 - Dewan, Renu (2006). The Socio-Economic Status of Tribal Women in Jharkhand. In Inside Jharkhand, edited by Sunil Kumar Singh, $6^{\text {Th }}$ ed., Ranchi: Crown Publications.

Erni, Luithu, 2012 - Erni, Christian, Shimreichon Luithu (2012). Violence, Customary Law and Indigenous Women's Rights In Asia. In End Violence against Women, Thailand: Asia Indigenous Peoples Pact.

Fernandes, Geeta, 1987 - Fernandes, Walter, Geeta Menon (1987). Tribal Women and Forest: Background and Methodology. In Tribal Women and Forest Economy: Deforestation, Exploitation and Status Change, edited by Walter Fernanades, Delhi: Indian Social Institute.

Fuchs, 1992 - Fuchs, Stephen (1992). Messianic Movement among the Tribal of NorthEastern Central India. In Godmen on the Warpath: A Study of Messianic Movement in India, New Delhi: Munshiram Manoharlal Publishers Pvt. Ltd.

George, 2014 - George, Ajitha S. (2014). Status Of Adivasis/Indigenous Peoples Mining: Jharkhand: An Adivasi Home Land.First.Series-2. Delhi: Aakar Books.

Gupta, 2001 - Gupta, Smita (2001). Backwardness of Jharkhand: A Study in Historical Perspective. In Backwardness of Jharkhand: Causes and Remedial Measures edited by L.N. Bhagat and U.K.Verma, $1^{\text {st }}$ ed. Chakradharpur: Jawahar Lal Nehru College.

Iyer, Maharaj, 1986 - Iyer, K. Gopal, R.N. Maharaj (1986). Agrarian Movement in Tribal Bihar (Dhanbad) 1972-80, edited by A.R. Desai, Delhi: Oxford University Press.

Jayaswal, Bhagat, 2001 - Jayaswal, Meera and R.N. Bhagat (2001). A Study of Attitude about Health Promotion among the Rural Tribal Women of Jharkhand. In Backwardness of Jharkhand: Causes and Remedial Measures edited by L.N. Bhagat and U.K.Verma, $1^{\text {st }}$ ed. Chakradharpur: Jawahar Lal Nehru College.

Jeyaraj, 2008 - Jeyaraj, Jesudason Baskar (2008). Biblical Theology Of Creation: A Basis for Human Rights. In Human Rights and Higher Education, edited by Lily Balasingh, Briget Mary, and Jesudason Jeyaraj, Madurai: Lady Doak College Publication.

Kannongo, 2001 - Kannongo, Sanghamitra (2001). Tribal and Human Rights. Delhi: Swastik Publication.

Khanna, 1998 - Khanna, SK (1998). Women and the Human Rights. $1^{\text {st }}$ ed. Common Wealth Publisher, New Delhi.

Kumari, 2001 - Kumari, Kalindi. (2001). Some Lessons from the History of Jharkhand

Movement. In Backwardness of Jharkhand: Causes and Remedial Measures edited by L.N. Bhagat and U.K.Verma, Chakradharpur: Jawahar Lal Nehru College.

Maharaj, Iyer, 1982 - Maharaj, R.N., K.G. Iyer (1982). Agrarian Movement in Dhandbad. In Fourth World Dynamics:Jharkhand, Delhi:Authors Guild Publications.

Mies, 1986 - Mies, Maria (1986). Patriarchy and Accumulation on a World Scale. Zed Books Ltd, London.

Mehta, 1982 - Mehta, Basant Kumar (1982). Historical and Cultural Basis of Jharkhandi Nationality. In Fourth World Dynamics: Jharkhand, edited by Nirmal Sengupta, Delhi:Authors Guild Publications.

Mitra, Mishra, 2013 - Mitra Manoshi, Mishra Sunil Kumar (2013). Child Migration, Child Trafficking and Child Labour in India, ILO Publication, New Delhi. 